\title{
The CONTRACT AS ANTI-CORRUPTION PlatForM FOR THE GLOBAL CORPORATE SECTOR
}

\author{
Jeffrey R. Boles*
}

\section{ABSTRACT}

Corrupt expenditures by distributors, consultants, and other third-party agents constitute one of the largest liability risks to global firms under the Foreign Corrupt Practices Act and other applicable anti-corruption laws. As globalization fuels corporate transactions and the vast scope of certain anti-corruption laws, companies have begun inserting anti-corruption provisions, varying widely in substance, into their contracts with business partners seeking protection from potential corrupt conduct by these business partners and attempting to shift risk of criminal penalties, administrative fines and damage claims to the corrupt actors. This Article considers from an international law perspective the substance, usage and overarching goals of these anti-corruption provisions in contracts between private parties, and in particular, corporate actors with an international presence. It analyzes how the provisions function as corporate due diligence tools, fusing contract and anti-corruption law in the context of third-party intermediary risk. It concludes by offering recommended drafting and enforcement models as a risk-reduction strategy to harmonize with corporate compliance programs, and it suggests legislative reforms to harness more effectively the benefits of provision usage from a public policy perspective.

I. BUSINESS CORRUPTION AND CORRESPONDING LEGAL REGULATION.. 811

A. Corruption Pervades the Private Sector.

B. International Anti-Corruption Enforcement Through

\footnotetext{
* Associate Professor, Department of Legal Studies, Fox School of Business, Temple University. Ph.D., 2006, University of California, Berkeley; J.D., 2006, University of California, Berkeley School of Law.
} 
Domestic Legislation and International Instruments

C. Attacking Corruption in the Private Sector Through the

Corporate Compliance Function...

II. CONTRACT LAW AS ANTI-CORRUPTION MECHANISM TO FIGHT THIRD-PARTY RISK

A. The Advent of Anti-Corruption Contractual Provisions as

Corporate Due Diligence Tools

B. Formalizing Anti-Corruption Contractual Provisions with

Model Clauses

C. Parties May Harness Broad Powers Through an Expanded

Range of Anti-Corruption Commitments

i. Representations \& Warranties Pertaining to AntiCorruption Compliance

ii. Rights to Conduct Audits on a Counterparty

iii. Addressing Infringement Through Termination, Suspension, Cooperation and Indemnification Rights

iv. Additional Rights, Restrictions, and Requirements Available by Contract

III. RECOMMENDATIONS FOR HARNESSING CONTRACTUAL LAW TO

FIGHT CORRUPTION IN THE CORPORATE SECTOR

A. Harmonizing Anti-Corruption Compliance Program

Operations with Contractual Provisions Through

Structured Risk Management.

B. Enhancing Anti-Corruption Initiatives Globally Through

Expansive Use of Anti-Corruption Provisions

C. Recognizing the Limitations of Anti-Corruption

Contractual Provisions for Corporate Actors

D. Encouraging the Usage of Anti-Corruption Provisions

Through Expanded Domestic Legislation \& Regulation

\section{INTRODUCTION}

In the current age of economic globalization and open-border commerce, the fight against corruption is developing into a worldwide movement flowing through the public and private sectors. Companies wishing to avoid prosecution for corruption-related offenses confront a growing and complex nexus of anti-corruption laws affecting their local and global operations, with non-compliance penalties posing significant criminal and civil liability coupled with reputational harm and potential exclusion from public contracts. Increased enforcement of anti-corruption 
law governing international commerce, including the Foreign Corrupt Practices Act (FCPA), Bribery Act 2010 (Bribery Act) and Criminal Code Act 1995 (Cth) in the United States, United Kingdom and Australia, respectively, has dramatically changed the global anti-corruption compliance landscape. ${ }^{1}$ Companies that operate internationally, or contract with third-party agents that do so, face increased scrutiny under these laws and the accompanying need to implement compliance measures to avoid prosecution. $^{2}$

The rise of anti-corruption legislation and enforcement has in turn shifted corporate culture towards a zero tolerance approach to bribery and other forms of corruption. Corresponding changes to corporate governance materialize in the formulation and implementation of internal anticorruption policies and practices, typically centralized through a compliance program designed to ensure adherence with external anticorruption regulations as they develop. Such programs properly structured can detect and address corrupt activity involving companies or their employees, with policies and practices incorporating anti-corruption principles that harmonize with existing legal and ethical obligations alongside business operations. The programs' features may include employee trainings, detailed codes of conduct, and anonymous and confidential reporting systems.

Heightened corruption risks surround third party agents, such as business development consultants, sales representatives, subcontractors, distributors, lawyers, accountants and other intermediaries, as they pose immense liability concerns for companies conducting international business indirectly through these third parties. ${ }^{3}$ The FCPA and Bribery Act, for example, impose liability upon organizations for the actions of their employees, distributors and other agents when acting on their principals' behalf. $^{4}$ Moreover, a majority of recently reported FCPA cases involve bribery schemes that rely upon third-party intermediaries, highlighting the prevalence of this corrupt practice. ${ }^{5}$

1. Ben Allen, Contracting Out of Corruption, LinkedIN (Mar. 2, 2015), https://www.li nkedin.com/pulse/contracting-out-corruption-can-done-ben-allen?trk=portfolio_articlecard_title [https://perma.cc/DC57-VCHC].

2. Id.

3. See F. Joseph Warin et al., The British are Coming!: Britain Changes its Law on Foreign Bribery and Joins the International Fight Against Corruption, 46 TEX. INT'L L.J. 1, 38 (2010) (explaining that both the FCPA and the Bribery Act require companies to develop internal control procedures that effectively prevent corruption).

4. 15 U.S.C. $\S 78 d d-2$ (a)(3) (2018); Bribery Act 2010, c. 23, §§ 7(1), 8(1) (U.K.). See also Warin et al., supra note 3, at 40-41 (comparing FCPA and Bribery Act provisions).

5. Arthur \& Toni Rembe Rock Center for Corporate Governance, Third Party Intermediaries, FCPA CLEARINGHOUSE (Jan. 7, 2019, 5:23 PM), http://fcpa.stanford.edu/cha 
Even with the most robust anti-corruption compliance program in place, a company cannot necessarily dictate how its third-party agents carry out their internal operations, and no company can guarantee that its agents will bring zero corruption risk. This exposure leaves companies vulnerable to corrupt acts, with the third party agents constituting "a chink in [organizations'] armour against bribery and corruption prosecution." Companies as a result "are alive to the risk of being tainted by the corrupt action of a counterparty," ${ }^{7}$ rendering third-party risk management a necessity for companies with any direct or indirect international operations.

To address third-party risk more effectively, the tools of contract law offer the private sector a form of protection from potential corrupt and unethical conduct arising from their consultants or other agents. Companies can include anti-corruption compliance provisions within their contracts with third-party intermediaries, and the provisions can fundamentally proscribe by contract any corrupt activity related to the contract while it remains in force. If properly drafted and enforced, the provisions may shield a company from corrupt acts perpetrated by its thirdparty intermediaries and in connection with any corresponding criminal, civil or administrative proceedings. ${ }^{8}$ Functioning as a warranty, the provisions may also serve as evidence that a company has not engaged in corrupt activity related to the contract prior to execution and during its lifetime. As the contract sets the bar for the principal-agent relationship, it offers a critical yet underutilized mechanism to help shield companies from criminal liability arising from this third-party risk.

While a party cannot contract out of criminal liability, anti-corruption contractual provisions may effectively shift liability risk such that it remains with the agent engaged in wrongdoing, provided such provisions are structured appropriately and integrated within a larger compliance program. Parties may draft anti-corruption contractual provisions to create mutual trust and cooperation, provide assurance of integrity, and protect the business relationship from the taint of corruption during the pre-contractual period through the lifespan of the contract. No set formula or governmentendorsed standards exist internationally in relation to recommended content of anti-corruption provisions, leaving companies with a plethora of

rt-intermediary.html [https://perma.cc/QB7K-N9T7] [hereinafter FCPA CLEARINGHOUSE].

6. Allen, supra note 1 .

7. Katherine Meloni \& Gabrielle Ereira, Anti-Corruption Provisions in Loan Documentation (2016), https://www.slaughterandmay.com/media/2536213/anti-corruptionprovisions-in-loan-documentation.pdf [https://perma.cc/JLV7-C79A].

8. Juan Francisco González Guarderas, What Should You Know when Entering into a Contract with an Anti-Corruption Clause? (Oct. 17, 2016), https://www.pbplaw.com/en/aque-me-obligo-cuando-firmo-contrato-clausula-anticorrupcion/ [https://perma.cc/NBK8HF4T]. 
protection options from which to choose. Provisions could address suitable record-keeping measures, adequate internal controls and procedures, ongoing monitoring, and objective audit, suspension, termination, and indemnification rights in connection with the agreement, among other possibilities.

This Article scrutinizes the synthesis between contract and anticorruption law in the context of third-party intermediary risk, explores the conceptual landscape and spectrum of anti-corruption contractual provisions available to business arrangements, and offers suggested models for drafting and enforcement as a risk-reduction strategy to minimize exposure in light of existing international anti-corruption legislation. Part I of the Article provides overviews of the nature of corruption in the corporate sector, international anti-corruption enforcement through domestic legislation and international instruments, and the role of the corporate compliance program to address anti-corruption obligations. Part II examines the origins and legal background of anti-corruption contractual provisions as a corporate due diligence tool in commercial agreements, critiques existing model clauses proffered by international organizations, and surveys the range of possible anti-corruption rights and obligations available to contracting parties. Part III concludes with recommendations for harmonizing balanced and commercially workable contractual provisions with anti-corruption compliance program operations through structured risk management, analyzes the potential legal shortcomings with such provisions, and suggests ways in which subsequent legislative efforts can capitalize upon the beneficial effects of provision usage from a public policy perspective.

\section{BUSINESS CORRUPTION AND CORRESPONDING LEGAL REGULATION}

\section{A. Corruption Pervades the Private Sector}

Corruption, the misuse of entrusted authority for private gain, permeates the private sector globally. ${ }^{9}$ Corrupt acts, such as bribery, fraud, abuse of power, embezzlement, extortion, and money laundering, entice perpetrators to gain a business advantage or garner illicit profit sub rosa, and research findings indicate such activity remains widespread across industries. ${ }^{10}$ The International Monetary Fund estimates that businesses

9. What Is Corruption?, TRANSPARENCY INT'L, https://www.transparency.org/what-iscorruption [https://perma.cc/VNV5-JCNW]; Engaging the Private Sector in the Fight Against Corruption, TRANSPARENCY INT'L, https://www.transparency.org/whatwedo/activity /engagingtheprivatesectorinthefightagainstcorruption [https://perma.cc/S4Y4-Z93R].

10. See Kathleen A. Lacey \& Barbara Crutchfield George, Crackdown on Money 
and individuals annually pay $\$ 1.5$ trillion in bribes, amounting to roughly $2 \%$ of global GDP. ${ }^{11}$ World Bank surveys from more than 135,000 firms across 139 countries show roughly 20 percent of such firms reported experiencing at least one bribery request. ${ }^{12}$

While no industry is immune, the energy, mining, construction, military defense, oil, telecommunications, medical and pharmaceutical, transportation and property development sectors are particularly prone to corruption. $^{13}$ Across industries, ever-present opportunities to engage in corruption could surface at seemingly any point in the lifecycle of a transaction. Corruption may insert itself, for instance, in an infrastructure or construction project's identification, financing, planning, design, tendering, execution, operation and/or maintenance phases. ${ }^{14}$

Deemed "the single greatest obstacle to economic and social development around the world," corruption ushers in economic, social, political and environmental harms to societies it touches. ${ }^{15}$ While companies may perceive that by engaging in corrupt acts, they may reap competitive advantages, empirical studies illustrate the damage corruption brings to the commercial realm. For example, empirical findings demonstrate that corruption creates operational inefficiencies in the business sector, requiring more employees to complete the same amount of work, ultimately making companies less productive. ${ }^{16}$ Firms operating in corrupt regions show inter alia more inefficient management practices,

Laundering: A Comparative Analysis of the Feasibility and Effectiveness of Domestic and Multilateral Policy Reforms, 23 Nw. J. INT'L L. \& Bus., 263, 303 (2003) (summarizing types of foreign corrupt activities); Corruption by Topic, TRANSPARENCY INT'L, https://www.trans parency.org/topic [https://perma.cc/P9BZ-GXZ8] (identifying industries prone to corruption).

11. Int'L Monetary Fund, Corruption: Costs and Mitigating Strategies 5 (2016), https://www.imf.org/ /media/Websites/IMF/imported-full-text-pdf/external/pubs/ft/ sdn/2016/sdn1605.ashx [https://perma.cc/C84R-BYM6].

12. World Bank Group, Enterprise Surveys: Corruption (Jan. 7, 2019), http://www.ente rprisesurveys.org/data/exploretopics/corruption [https://perma.cc/2XJD-YTM8].

13. OECD, Foreign Bribery Fact Sheet 1 (Oct. 2014), https://www.oecd.org/daf/antibribery/Foreign_Bribery_Factsheet_ENGLISH.pdf [https://perma.cc/B9HQ-BDXQ].

14. GIACC, How Corruption Occurs (Jan. 30, 2013), http://www.giaccentre.org/how_c orruption_occurs.php [https://perma.cc/6V5M-GPAA].

15. UNODC, 'It's a Crime': Corruption (Feb. 12, 2015), http://www.unodc.org/unodc/ en/frontpage/2015/February/its-a-crime_corruption.html [https://perma.cc/UF5M-SH3C]. See generally Susan Rose-ACKerman \& Bonnie J. PALIFKA, Corruption AND GOVERnMENT: CAUSES, CONSEQUENCES, AND REFORM 27-36 (2d ed. 2016) (summarizing empirical findings addressing the effects of corruption); Philip M. Nichols, The Business Case for Complying with Bribery Laws, 49 AM. Bus. L.J. 325, 338-40 (2012) (analyzing harmful economic effects of corruption in the business sector).

16. Ernesto Dal Bóa \& Martín A. Rossi, Corruption and Inefficiency: Theory and Evidence from Electric Utilities, 91 J. PuB. ECON. 939, 958-60 (2007). 
smaller product markets, lower export prospects, and lower levels of innovation and R\&D investment. ${ }^{17}$ Indeed, a large academic consensus identifies the corrosive impact of corruption on economic growth. ${ }^{18}$

\section{B. International Anti-Corruption Enforcement Through Domestic Legislation and International Instruments}

Most countries outlaw bribery and other forms of corruption through domestic legislation, and many use criminal sanctions and civil penalties with supplemental regulatory action to enforce and deter. ${ }^{19}$ Typically an anti-corruption law extends its reach to transactions occurring within the respective jurisdiction, but a number of countries have enacted expansive criminal legislation with extraterritorial scope that forbids bribes to foreign officials in international transactions. ${ }^{20}$ The FCPA and Bribery Act are perhaps the most prominent examples of such an approach.

The United States enacted the FCPA in 1977 to outlaw payments to foreign government officials that are made to assist in securing or retaining business. ${ }^{21}$ The first criminal statute to outlaw international corruption, it prohibits individuals and companies from corruptly offering, promising, or providing anything of value to foreign officials in order to secure or retain an improper advantage ${ }^{22}$ and requires companies whose securities are listed in the United States to maintain books and records that accurately and

17. Daphne Athanasouli \& Antoine Goujard, Corruption and Management Practices: Firm Level Evidence, 43 J. Comp. ECON. 1014, 1032 (2015).

18. See, e.g., Transparency Int'l, The Impact of Corruption on Growth and Inequality (Mar. 15, 2014), https://www.transparency.org/files/content/corruptionqas/Impact_of _corru ption_on_growth_and_inequality_2014.pdf [https://perma.cc/S5E6-CALT] (examining how corruption "adversely affect[s] long-term economic growth through its impact on investment, taxation, public expenditures and human development"); Giorleny D. Altamirano, The Impact of the Inter-American Convention Against Corruption, 38 U. MIAMI INTER-AM. L. REV. 487, 492-97 (2007) (discussing research findings regarding the negative impact of corruption on the economy).

19. See Jeffrey R. Boles, Criminalizing the Problem of Unexplained Wealth: Illicit Enrichment Offenses and Human Rights Violations, 17 N.Y.U. J. LeGIS. \& PuB. PoL'y 835, 842 (2015) (providing an overview of international anti-corruption efforts).

20. See, e.g., 15 U.S.C. § 78dd-1 (2018); Antonio Argandoña, The 1996 ICC Report on Extortion and Bribery in International Business Transactions, 6 Bus. ETHICs 134, 136 (1997) (discussing countries enacting anti-corruption legislation).

21. See Gideon Mark, Private FCPA Enforcement, 49 AM. Bus. L.J. 419, 422 (2012) (providing a brief history of the FCPA).

22. 15 U.S.C. $\S \S 78 \mathrm{~m}, 78 \mathrm{dd}-1-78 \mathrm{dd}-3$, 78ff (2018). Accord Rahul Kohli, Foreign Corrupt Practices Act, 55 AM. CRIM. L. Rev. 1269, 1301 (2018) ("No other country enacted a similar piece of anti-bribery legislation until 1997 when the international community began to take substantial steps to criminalize corruption in transnational commercial dealings."). 
fairly reflect the companies' transactions and maintain an adequate system of internal accounting controls. ${ }^{23}$ Due to its broad jurisdictional interpretation, the law extends its reach extraterritorially to business transactions conducted entirely outside of the U.S. ${ }^{24}$ Moreover, general corporate liability principles apply to the FCPA, rendering a company liable for FCPA violations through the actions of its officers, directors, employees, or agents acting within the scope of their employment and intended to benefit the company. ${ }^{25}$

The United Kingdom enacted the Bribery Act in $2010^{26}$ to modernize and strengthen its anti-bribery laws, creating what "has been widely received as one of the most far-reaching anti-bribery laws of any country or international organization." ${ }^{27}$ The Bribery Act criminalizes active bribery (offering, promising or giving a bribe), passive bribery (requesting, accepting or agreeing to receive a bribe), commercial bribery (private-toprivate bribery), and bribery of a foreign official to obtain or retain business or advantage in conducting business. ${ }^{28}$ It also creates a new type of corporate liability in the failure of a commercial organization to prevent bribery by persons associated with it. ${ }^{29}$ This latter provision, the first of its kind globally, effectively imposes strict liability for organizations that fail to prevent bribery by their employees or agents, ${ }^{30}$ and its broad extraterritorial reach covers any entity that conducts "part of a business" in the U.K. ${ }^{31}$ The Act tempers its "failure to prevent" offense with a full defense available to any organization that has implemented adequate

23. 15 U.S.C. $\S \S 78 \mathrm{~m}(\mathrm{~b})(2)(\mathrm{A})-(\mathrm{B})$.

24. See Peter W. Schroth, The United States and the International Bribery Conventions, 50 Ам. J. CомP. L. 593, 602-04 (2002) ("In its current form, the FCPA purports to reach foreigners who have virtually any sort of contact with the United States in furtherance of a violation of the act and U.S. nationals who do anything in furtherance of such a violation anywhere in the world.").

25. See U.S. Dept. of Justice \& U.S. Secs. \& Exch. Comm'n, A Resource Guide to THE U.S. FOREIGN CORRUPT PRACTICES ACT 27 (2012), https://www.sec.gov/spotlight/fcpa/f cpa-resource-guide.pdf [https://perma.cc/LT7N-GPYW] [hereinafter FCPA RESOURCE GUIDE] (discussing corporate liability principles for bribery violations).

26. Bribery Act 2010, c. 23 (Eng.).

27. Kohli, supra note 22, at 1307.

28. Bribery Act 2010, c. 23, $\S 1,2,6$ (Eng.).

29. Id. at $\S 7$.

30. Warin et al., supra note 3, at 38.

31. Jon Jordan, Recent Developments in the Foreign Corrupt Practices Act \& the New UK Bribery Act: A Global Trend Towards Greater Accountability in the Prevention of Foreign Bribery, 7 N.Y.U. J.L. \& Bus. 845, 866 ("'[A]ny international corporation that does any kind of business in the [U.K.] can be held criminally liable for failure to prevent bribery even when the corporation is not based in the [U.K.], the offensive bribe did not take place in the [U.K.], or the recipient of the bribe is not from the [U.K.]."). 
procedures to prevent bribery by persons associated with it. ${ }^{32}$

A growing, cross-border anti-corruption regime recently surfaced to coordinate national enforcement system efforts and encourage the development of domestic criminal legislation. ${ }^{33}$ The anti-bribery measures of international organizations largely facilitated the growth of this infrastructure, as the organizations' multilateral agreements require signatory nations to maintain criminal laws that penalize corruption and to implement other anti-corruption mechanisms. ${ }^{34}$ The 1997 OECD Convention on Combatting Bribery of Foreign Public Officials in International Business Transactions, ${ }^{35}$ the 1999 Council of Europe Criminal Law Convention on Corruption, ${ }^{36}$ and the 2003 United Nations Convention against Corruption ${ }^{37}$ for instance require signatory countries to criminalize bribery involving foreign public officials, and the agreements significantly facilitated the development of transnational bribery laws. ${ }^{38}$ These collective efforts propelled the global anti-corruption movement, with most nations now retaining substantive laws that prohibit various corrupt activities. $^{39}$

32. Bribery Act 2010 , c. 23 , $§ 7$ (Eng.). Accord Ministry of Justice, The Bribery ACT 2010: GUIDANCE 8 (2011), https://assets.publishing.service.gov.uk/government/uploads/ system/uploads/attachment_data/file/181762/bribery-act-2010-guidance.pdf

[https://perma.cc/8PCK-7UWG] [hereinafter BRIBERY ACT GUIDANCE] ("The defence is also included in order to encourage commercial organisations to put procedures in place to prevent bribery by persons associated with them."). The FCPA does not contain a similar defense. Jon Jordan, The Adequate Procedures Defense Under the UK Bribery Act: A British Idea for the Foreign Corrupt Practices Act, 17 STAN. J.L. Bus. \& Fin. 25, 33 (2011).

33. See Thomas R. Snider \& Won Kidane, Combating Corruption Through International Law in Africa: A Comparative Analysis, 40 CORNELL INT’L L.J. 691, 698-711 (2007) (detailing international anti-corruption initiatives).

34. See, e.g., Peter J. Henning, Public Corruption: A Comparative Analysis of International Corruption Conventions and United States Law, 18 ARIZ. J. INT'L \& CoMP. L. 793, 813-14 (2001) (explaining that Article IX of the IACAC requires signatory nations to adopt laws that criminalize an inexplicable increase in a government official's assets).

35. OECD, Convention on Combating Bribery of Foreign Public Officials in International Business Transactions and Related Documents 7 (2011), http://www.oecd.org/ daf/anti-bribery/ConvCombatBribery_ENG.pdf [https://perma.cc/E58P-RZ89].

36. Criminal Law Convention on Corruption, CounCIL EuR. (Jan. 27, 1999), http://con ventions.coe.int/Treaty/en/Treaties/Html/173.htm [https:/perma.cc/AF7T-2FSH].

37. G.A. Res. 58/4, annex, art. 16, U.N. Doc. A/RES/58/4/Annex, Convention Against Corruption (Oct. 31, 2003).

38. See Jeffrey R. Boles, The Two Faces of Bribery: International Corruption Pathways Meet Conflicting Legislative Regimes, 35 Mich. J. InT'L L. 673, 680 (2014); see also TRACE, GlOBAL ENFORCEMENT REPORT 2011 (2011), https://www.strtrade.com/m edia/publication/6092_2011-August-19-fcpa_report.pdf [https://perma.cc/4UXU-2ANN] ("The goal of such laws and conventions is to create a fair and transparent international business market rather than one skewed by under-the-table deals that enrich government officials at the expense of their fellow citizens.").

39. See Benjamin B. Wagner \& Leslie Gielow Jacobs, Retooling Law Enforcement to 


\section{Attacking Corruption in the Private Sector Through the Corporate Compliance Function}

A self-policing private sector is necessary to fight corruption effectively, and governments can incentivize organizations to self-police and cooperate through reward-and-penalty approaches. ${ }^{40}$ To manage the massive issue of identifying and investigating corporate wrongdoing, particularly involving crimes like international bribery that may be virtually impossible to detect without corporate admission, governments can employ the threat of corporate criminal liability with the prospect of leniency as a dual mechanism to induce companies to monitor their own agents, identify wrongdoing, and make disclosures to the relevant government agency. ${ }^{41}$ In doing so, governments shift the investigatory burden to companies, easing the practical difficulties governments face with the expensive and timeconsuming nature of investigatory work, the complexity of corporate accounting and bookkeeping, and limited budgets. ${ }^{42}$

The U.S. Sentencing Guidelines demonstrate this carrot-and-stick approach by offering to reward organizations that voluntarily disclose violations, cooperate with law enforcement, and "promote an organizational culture that encourages ethical conduct and a commitment to compliance with the law" with a reduction in offense level. ${ }^{43}$ The U.K.

Investigate and Prosecute Entrenched Corruption: Key Criminal Procedure Reforms for Indonesia and Other Countries, 30 U. PA. J. INT'L L. 183, 194 (2008) (“"[M]ost developing countries now have a range of substantive provisions prohibiting bribery and other acts of public corruption.").

40. Julie R. O'Sullivan, Some Thoughts on Proposed Revisions to the Organizational Guidelines, 1 OHIo ST. J. CRIM. L. 487, 494 (2004) (examining how a corporation's liability exposure can significantly be reduced resulting from awarded credits for compliance programs, self-reporting, cooperation during the investigative stage, and accepting responsibility).

41. Rachel Brewster \& Samuel W. Buell, The Market for Global Anticorruption Enforcement, 80 LAW \& CONTEMP. ProBs. 193, 211 (2017).

42. Robert S. Bennett et al., From Regulation to Prosecution to Cooperation: Trends in Corporate White Collar Crime Enforcement and the Evolving Role of the White Collar Criminal Defense Attorney, 68 Bus. LAw. 411, 417 (2013). Accord, William R. McLucas et al., The Decline of the Attorney-Client Privilege in the Corporate Setting, 96 J. CRIM. L. \& CRIMINOLOGY 621, 639 (2006) (examining how "private lawyers are effectively 'deputized' in many internal investigations, and the government obtains the facts of their inquiry through waiver of attorney-client privilege").

43. U.S. Sentencing Guidelines Manual § 8B2.1(a)(2) (U.S. Sentencing Comm’N 2004); Justice Manual $§ 9-28.300$ (U.S. Dep'T OF Justice 2018), https://www.justice.gov/jm/jm-9-28000-principles-federal-prosecution-business-organizatio ns\#9-28.300 [https://perma.cc/JU6S-62VN] (discussing factors to be considered when deciding whether to bring charges against a corporate target, including, inter alia, "the corporation's willingness to cooperate, including as to potential wrongdoing by its agents"). 
follows a similar approach, ${ }^{44}$ and a number of international instruments also advocate for companies to adopt and implement compliance programs and codes of conduct. ${ }^{45}$ With this growing dynamic, multinational companies have legal and financial incentives to exercise diligence in detecting and preventing wrongdoing and to sustain an ethical corporate culture with an effective compliance program. ${ }^{46}$

Compliance programs constitute a fundamental component of a company's enterprise risk management and internal controls framework that assesses the operative risks and realities inherent in the company's operations. ${ }^{47}$ Properly structured compliance programs can effectively detect and address instances of corruption involving companies or their agents, with such anti-corruption practices serving to protect corporate reputations and stakeholder interests. ${ }^{48}$ While no compliance program could detect every instance of criminal activity involving a company, critical factors inherent in any program, from the lens of the Department of Justice (DOJ), center upon "whether the program is adequately designed for maximum effectiveness in preventing and detecting wrongdoing by employees and whether corporate management is enforcing the program or

44. BRIBERY ACT GUIDANCE, supra note 32, at 8 ("The commercial organisation's willingness to co-operate with an investigation under the Bribery Act and to make a full disclosure will also be taken into account in any decision as to whether it is appropriate to commence criminal proceedings."); Kevin J. Smith, The Foreign Corrupt Practices Act: Set Aside the Moral and Ethical Debates, How Does One Operate Within This Law?, 45 HOFSTRA L. REV. 1119, 1134-35 (2017) (comparing U.S. and U.K. approaches).

45. See, e.g., OECD, Recommendation of the Council for Further Combating Bribery of Foreign Public Officials in International Business Transactions $\S \S$ III, X (Nov. 26, 2009), https://www.oecd.org/daf/anti-bribery/44176910.pdf [https://perma.cc/47C6-4LWY] (recommending that its signatory countries adopt business sector requirements regarding the implementation of accounting, external audit, internal control, ethics, and compliance requirements and practices in order to detect and prevent bribery of foreign public officials).

46. Maurice E. Stucke, In Search of Effective Ethics \& Compliance Programs, 39 J. CoRP. L. 769, 775 (2014). But see United States v. Potter, 463 F.3d 9, 25-26 (1st Cir. 2006) (noting that a corporation cannot "avoid liability by adopting abstract rules" that prohibit its agents from engaging in illegal conduct, as "[e]ven a specific directive to an agent or employee or honest efforts to police such rules do not automatically free the company for the wrongful acts of agents"); JuSTICE MANUAL § 9-28.800 (U.S. DEP'T OF JuSTICE 2019), https://www.justice.gov/jm/jm-9-28000-principles-federal-prosecution-business-organizatio ns\#9-28.800 [https://perma.cc/XC2J-Y3PM] ("[T]he existence of a compliance program is not sufficient, in and of itself, to justify not charging a corporation for criminal misconduct undertaken by its officers, directors, employees, or agents.").

47. Stucke, supra note 46, at 776-79.

48. Neha Das, Eliminate Corruption to Build Sustainable, Inclusive and Transparent Societies, United Nations Global COMPACT, https://www.unglobalcompact.org/what-is-g c/our-work/governance/anti-corruption [https://perma.cc/P4V3-NUBH] (discussing how mobilizing business can provide a united voice against corruption, as "[c]ollective action is essential for bringing an end to a systemic issue that is too complex for any company to tackle alone"). 
is tacitly encouraging or pressuring employees to engage in misconduct to achieve business objectives." 49

There is no set formula for structuring a compliance program, but prosecutors, when assessing such programs, typically examine whether a program is well designed, effective in application, and applied earnestly and in good faith, as they differentiate between mere "paper programs" and suitably designed and implemented programs that are reviewed and revised as appropriate. ${ }^{50}$ Companies with effective programs maintain sufficient compliance staff to document, analyze, utilize and audit results from the programs and provide adequate training to employees and other agents regarding the program's operations and company's commitment to the program. $^{51}$ Such programs tailor their functions to align with the fundamentals of company product lines or services and attendant market supply chain and work force, the degree of regulation and government interaction, and the extent to which the company operates in countries with a high risk of corruption. ${ }^{52}$

Through its operations, an effective compliance program bridges legal, risk management and ethics policy and practice by thwarting corruption and other illicit activity in a risk-based approach tailored to the company's industry, size and location and focused upon identified corruption risks and schemes. ${ }^{53}$ Such a compliance program can deter corruption from multiple angles by overseeing proper accounting and auditing practices that ensure all firm expenditures have been authorized and accounted for, taking appropriate disciplinary action against any employee or agent who has violated company anti-corruption policies, and providing an anonymous reporting system where any employee or agent can report apparent anti-corruption policy violations without fear of

49. Justice Manual $\S$ 9-28.800.B (U.S. DeP’T OF Justice 2019), https://www.justice.g ov/jm/jm-9-28000-principles-federal-prosecution-business-organizations \#9-28.800 [https://p erma.cc/4AA6-B2SR].

50. Id.

51. Id.; BRIBERy ACT GuIDANCE, supra note 32, at 20-31 (detailing its six guiding principles for effective compliance programs).

52. FCPA RESOURCE GuIDE, supra note 25, at 40.

53. Professors David Hess and Thomas Dunfee have argued that, to impact corrupt practices, a company's anti-corruption principles "must (1) emphasize transparency; (2) provide guidance concerning specific practices associated with paying bribes; (3) be relevant to organizational environments; (4) identify itself with and be supported by an independent entity such as a non-governmental organization or an academic center, and, perhaps most importantly; (5) be capable of monitoring and assessment by external, independent entities, such as social and financial auditors." David Hess \& Thomas W. Dunfee, Fighting Corruption: A Principled Approach; The $C^{2}$ Principles (Combating Corruption), 33 CORNELl INT'L L.J. 593, 618 (2000). 
retribution. $^{54}$

\section{CONTRACT LAW AS ANTI-CORRUPTION MECHANISM TO FIGHT THIRD-PARTY RISK}

\section{A. The Advent of Anti-Corruption Contractual Provisions as Corporate Due Diligence Tools}

Business development consultants, sales representatives, subcontractors, distributors, lawyers, accountants and other intermediaries pose corruption risks that constitute massive liability concerns for companies conducting overseas business indirectly through such third parties. ${ }^{55}$ The FCPA and Bribery Act impose liability upon organizations for the actions of their employees, distributors and other third-party agents when acting on their principals' behalf. ${ }^{56}$ Recent FCPA enforcement actions show how third-party intermediaries frequently engage in international business transactions and attempt to conceal bribery payments to foreign officials. ${ }^{57}$ Roughly ninety percent of all recently reported FCPA cases involve bribery schemes that rely upon third-party intermediaries, rendering third-party risk management a critical concern for companies with overseas operations. ${ }^{58}$

In apparent recognition of the fulsome liability danger, the primary internationally recognized business instruments on anti-bribery, including those from the World Bank, OECD, International Chamber of Commerce (ICC), and Transparency International, offer guidance on internal controls and compliance practices pertaining to third-party risk in order to assist companies in addressing this precarious area. ${ }^{59}$ The instruments advocate for the adoption of corporate policies that support third-party compliance with anti-corruption rules. ${ }^{60}$ Recurring advice in such instruments surrounds the need to conduct "properly documented risk-based due

54. Id. at 621.

55. Warin et al., supra note 3, at 38 .

56. 15 U.S.C. $\S 78 d d-2(a)(3)$ (1998); Bribery Act 2010, c. 23, §§ 7(1), 8(1) (Eng.); see also Warin et al., supra note 3, at 40-41 (comparing the FCPA and Bribery Act provisions).

57. KPMG, THIRD-PARTY RISK MANAGEMENT 2-3 (2014), https://advisory.kpmg.us/co ntent/dam/advisory/en/pdfs/third-party-risk-management-2014.pdf [https://perma.cc/87MV$\mathrm{B} 86 \mathrm{R}]$.

58. FCPA CLEARINGHOUSE, supra note 5.

59. OECD et al., Anti-Corruption Ethics and Compliance Handbook for BUSINESS 38-46 (2013), https://www.oecd.org/corruption/Anti-CorruptionEthicsComplianc eHandbook.pdf [https://perma.cc/4D6B-QVHR] (detailing provisions of business guidance instruments on anti-bribery).

60. Id. 
diligence pertaining to the hiring, as well as the appropriate and regular oversight of business partners," ${ }^{61}$ to notify business partners of a company's commitment to abiding by the terms of applicable anti-bribery laws and of the company's compliance program addressing anti-bribery practices, and to seek a reciprocal commitment from business partners. ${ }^{62}$

To mitigate the risk that third-party payments will constitute bribery violations, many companies now implement extensive compliance policies and practices that govern third-party intermediary conduct as part of their due diligence processes. ${ }^{63}$ One due diligence process in particular, the inclusion of anti-corruption compliance provisions in agreements with third-party intermediaries, has been recognized as one of the most effective ways to mitigate liability risks posed by third parties. ${ }^{64}$ If structured and enforced properly, the provisions may effectively protect a company from corrupt acts perpetrated by its third-party intermediaries and in connection with any resulting criminal, administrative or civil proceedings. ${ }^{65}$

These provisions essentially prohibit by contract third-party intermediaries and their agents from engaging in any corrupt activity related to the contract while it remains in force. Moreover, the provisions may provide evidence that a company has not paid bribes or otherwise engaged in corrupt activity related to the contract prior to the contract's

61. OECD, Good Practice Guidance on Internal Controls, Ethics, and Compliance § A.6.i (Feb. 18, 2010), https://www.oecd.org/daf/anti-bribery/44884389.pdf [https://perma. cc/YW66-U56S] [hereinafter Good Practice Guidance]. See also World Bank Grp., World Bank Group Integrity Compliance Guidelines § 5.1 (Sept. 2010), http://siteresources.worldb ank.org/INTDOII/Resources/Integrity_Compliance_Guidelines.pdf [https://perma.cc/2EHX277T] [hereinafter Integrity Compliance Guidelines] ("Conduct properly documented, riskbased due diligence (including to identify any beneficial owners or other beneficiaries not on record) before entering into a relationship with a business partner, and on an ongoing basis").

62. Good Practice Guidance, supra note 61, at § A.6.ii-iii.

63. Warin et al., supra note 3 , at 40 (discussing diligence regarding FCPA risks of third-party business partners); Priya Cherian Huskins, FCPA Prosecutions: Liability Trend to Watch, 60 Stan. L. Rev. 1447, 1456 (2008).

64. See Kohli, supra note 22, at 1322 ("Addressing FCPA compliance in the formative contract is widely recognized as the best way to mitigate risks posed by 'red flag' transactions."); Daniel J. Grimm, Traversing the Minefield: Joint Ventures and the Foreign Corrupt Practices Act, 9 VA. L. \& Bus. ReV. 91, 146 (2014) ("FCPA risks can be further reduced by including various contractual provisions within joint-venture agreements and contracts with third parties."); Meloni \& Ereira, supra note 7, at 1 (discussing usage of anticorruption provisions in English law loan documentation); Neil McInnes, Addressing the Bribery Act in Your Contracts: A Tiered Approach, Construction Blog (June 13, 2012), http://constructionblog.practicallaw.com/addressing-the-bribery-act-in-your-contracts-a-tier ed-approach/ [https://perma.cc/CZT8-NA8T] (analyzing effective use of anti-corruption clauses in supply chain and subcontractor contracts).

65. Guarderas, supra note 8. 
execution and during its lifetime. ${ }^{66}$

Government agencies through earlier enforcement activity served as initial catalysts to raise private sector awareness on the use of anticorruption contractual provisions with third-party agents. They have required defendants in enforcement actions to insert anti-corruption provisions in their third-party contracts as part of their larger due diligence compliance efforts. For instance, defendant Metcalf \& Eddy agreed as part of its consent agreement with the DOJ in 1999 to implement an anticorruption compliance program where contracts with its agents and other representatives include a clause stating that the parties will not offer bribes and that the counterparty agent will not employ a sub-agent without the prior written consent of Metcalf \& Eddy. ${ }^{67}$ The DOJ also endorsed the use of anti-corruption compliance provisions in third-party contracts through issued opinions ${ }^{68}$ and deferred prosecution agreements, ${ }^{69}$ and the SEC has noted in prior complaints whether defendants contractually bound their third-party consultants to comply with the FCPA. ${ }^{70}$

The U.K. Ministry of Justice likewise advocates for firms to follow this approach. ${ }^{71}$ It strongly advocates for companies to employ anti-

66. Guarderas, supra note 8.

67. Consent \& Undertaking of Metcalf \& Eddy, Inc. at $\S 4 . i$, United States v. Metcalf \& Eddy, Inc., No. 99-cv-12566 (D. Mass. 1999), http://fcpa.stanford.edu/fcpac/documents/40 00/002858.pdf [https://perma.cc/763N-938G]. This case constitutes the first instance where the DOJ provided a detailed list of features that a defendant corporation should include in a remedial compliance and ethics program; Philip Urofsky et al., How Should We Measure the Effectiveness of the Foreign Corrupt Practices Act? Don't Break What Isn't Broken-The Fallacies of Reform, 73 OHIO ST. L.J. 1145, 1153-54 (2012).

68. See U.S. Dep't of Justice, FCPA Opinion Procedure Release 2008-02 (June 13, 2008), https://www.justice.gov/sites/default/files/criminal-fraud/legacy/2010/04/11/0802.pd f [https://perma.cc/WE6N-3EP5] [hereinafter DOJ Release 2008-02] ("All agents and other third parties ... will as soon as commercially reasonable be required to sign new contracts ... with Halliburton that incorporate appropriate FCPA and anti-corruption representations and warranties, anti-corruption provisions, and audit rights, as provided for under Halliburton's Code of Business Conduct and related policies and procedures.").

69. See Deferred Prosecution Agreement at C-7, United States v. Panalpina World Transp. (Holding) Ltd., No. 4:10-cr-00769 (S.D. Tex. Nov. 4, 2010), https://www.justice.g ov/sites/default/files/criminal-fraud/legacy/2011/02/16/11-04-10panalpina-world-dpa.pdf [h ttps://perma.cc/J7PL-FG76] ("Panalpina will include standard provisions in agreements, contracts, and renewals thereof with all agents and business partners that are reasonably calculated to prevent violations of the anticorruption laws ....").

70. See Complaint at 17, Secs. \& Exch. Comm'n v. Avon Prods., Inc., No. 14-CV9956 (S.D.N.Y. Dec. 17, 2014), https://www.sec.gov/litigation/complaints/2014/comp-pr20 14-285.pdf [https://perma.cc/5Z47-3BYR] ("Avon Products China did not contractually bind Consulting Company 1 to comply with the FCPA.").

71. See BRIBERY ACt GuidANCE, supra note 32, at 39 (endorsing the use of suitable contractual terms on bribery prevention measures in agreements between parties). Notably, the U.S. Sentencing Commission in its Sentencing Guidelines for Organizations does not explicitly address the use of anti-corruption contractual provisions, but comments that large 
corruption provisions with counterparties in their supply chain:

The principal way in which commercial organisations may decide to approach bribery risks which arise as a result of a supply chain is by employing the types of anti-bribery procedures referred to elsewhere in this guidance (e.g. risk-based due diligence and the use of anti-bribery terms and conditions) in the relationship with their contractual counterparty, and by requesting that counterparty to adopt a similar approach with the next party in the chain.

Scholars and practitioners have also endorsed the application of anticorruption contractual provisions to corporate business partners and stressed their utility in helping to control difficulties companies face in complying with anti-corruption laws. ${ }^{73}$ David Hess \& Thomas Dunfee have highlighted how agents, particularly those that facilitate sales and marketing, are often conduits by which firms make payments, and such firms may not be aware of their sales and marketing agents making improper payments to government officials using commissions and fees. ${ }^{74}$ Their anti-corruption C2 Principles require firms to obtain from all of their suppliers affirmation that the suppliers have not and will not make improper payments in any contract to which the firm is a party. ${ }^{75}$

Others note how anti-corruption contractual provisions containing appropriate remedies for breach ${ }^{76}$ may prevent a company from having to choose between continuing an agreement that raises corruption risks or subsequently breaching the agreement due to previously unknown corruption liability. ${ }^{77}$ The provisions may allow the company to exit the

organizations should encourage smaller organizations that seek to contract with them to implement effective compliance and ethics programs. U.S. SENTENCING GuIDELINES MANUAL $\S$ 8B2.1(b) cmt. 2(C)(ii) (U.S. SENTENCING COMM’N 2004).

72. BRIBERY ACT GUIDANCE, supra note 32, at 16.

73. See Ike Adams \& Robert Keeling, Vicarious Liability Risks Facing the Financial Industry under the FCPA, 9 GEO. MASON J. INT'L COM. L. 1, 32 (2017) (advocating for "appropriate contractual representations with third-party intermediaries relating to compliance with the FCPA and relevant foreign anti-corruption laws"); Christopher F. Corr \& Judd Lawler, Damned If You Do, Damned If You Don't? The OECD Convention and the Globalization of Anti-Bribery Measures, 32 VAND. J. TRANSNAT'L L. 1249, 1343 (1999) (urging multinational companies to adopt anti-corruption measures to mitigate the risk that emanates from dealings with other businesses).

74. Hess \& Dunfee, supra note 53, at 622.

75. Hess \& Dunfee, supra note 53, at 621. Designed for voluntary adoption by firms, the $\mathrm{C} 2$ Principles "require firms to implement procedures to prevent the payment of bribes and to publicly disclose their progress and efforts towards these ends." Hess \& Dunfee, supra note 53, at 594.

76. See infra Part II.C.iii (examining termination rights).

77. Kohli, supra note 22, at 1322. 
contractual relationship cleanly. ${ }^{78}$

Warin and colleagues emphasize the benefits of combining anticorruption contractual provisions with appropriate due diligence on a third party, as such a combination may significantly decrease the likelihood that prosecutors would allege that a company "consciously disregarded or remained deliberately ignorant of the possibility of a corrupt payment, even if the third party does make such a payment." 79 Beyond reducing the risk of prosecution, companies that include properly enforced anti-corruption contractual provisions in their third-party contracts may pursue a private cause of action against their agents for breach of contract if the agents materially violate the provisions. ${ }^{80}$

\section{B. Formalizing Anti-Corruption Contractual Provisions with Model Clauses}

While the benefits of anti-corruption contractual provisions have been recognized for roughly two decades, there has been no apparent consensus or uniform approach regarding when to require such provisions in a contract or what types of anti-corruption commitments within which to include. $^{81} \quad$ For instance, many international anti-bribery business instruments stress the importance of including anti-corruption commitments in contracts with business partners but differ in the specific types of commitments and breach remedies they recommend. ${ }^{82}$

To illustrate, the OECD Good Practice Guidance on Internal Controls, Ethics and Compliance advises companies to consider informing their business partners of their anti-corruption commitments and ethics and compliance program and to seek "a reciprocal commitment from business partners." ${ }^{83}$ The World Economic Forum's PACI Principles for Countering Bribery (the PACI Principles) advises that an enterprise's "agent, adviser or other intermediary should contractually agree in writing to comply with the enterprise's [compliance program]" and that "[p]rovision should be included in all contracts with agents, advisers and other intermediaries relating to access to records, cooperation in investigations and similar

78. Grimm, supra note 64 , at $146-47$.

79. Warin et al., supra note 3, at 41.

80. Brian C. Harms, Holding Public Officials Accountable in the International Realm: A New Multi-Layered Strategy to Combat Corruption, 33 Cornell InT'L L.J. 159, 205 n.290 (2000).

81. See McInnes, supra note 64 (noting that the Ministry of Justice guidance does not provide detail on anti-bribery terms and conditions).

82. See supra Part II.A (discussing recommendations of international anti-bribery instruments).

83. Good Practice Guidance, supra note 61 , at $\S$ A.6.ii. 
matters pertaining to the contract." 84 Regarding breach of an anticorruption provision, the PACI Principles advise that an enterprise "should monitor the conduct of its agents, advisers and other intermediaries and should have a contractual right of termination in case of conduct inconsistent with the [enterprise's compliance program]. ${ }^{, 85}$

Providing companies with more concrete direction, the International Chamber of Commerce (ICC) in 2012 published a model anti-corruption clause (ICC Clause) as guidance "designed to be applied by enterprises of any size, whether large, medium or small." provide parties with a contractual provision that will reassure them about the integrity of their counterparts during the pre-contractual period as well as during the term of the contract and even thereafter," and offers two contractual alternatives that parties can insert into a contract, with the first constituting a more substantive anti-corruption undertaking by the parties. ${ }^{87}$

This first alternative incorporates Part I of the ICC Rules on Combating Corruption (ICC Rules), ${ }^{8}$ where each party agrees that it, its officers, directors, or employees "have not offered, promised, given, authorized, solicited or accepted any undue ... advantage . . in any way connected with the [c]ontract and that it has taken reasonable measures to prevent ... third parties, subject to its control or determining influence, from doing so." 89

The parties also agree that, "at all times in connection with and throughout the course of the [c]ontract and thereafter," they will not engage in bribery, extortion or solicitation, trading in influence or money

84. World ECON. Forum, ANTI-CORRUPTION HANDBOOK: Implementing the PACI PRINCIPLES FOR COUNTERING BRIBERY 31 (2007), https://www.compliance-instituut.nl/wpcontent/uploads/PACI-Implementation-Handbook.pdf [https://perma.cc/4JEE-AKHM].

85. Id. The World Bank Group Integrity Compliance Guidelines similarly recommend the inclusion of a contractual termination right in the event of a business counterparty's corrupt misconduct. Integrity Compliance Guidelines, supra note 61, at $\S 6.2$ (advising that business partner contracts should include "express contractual obligations, remedies and/or penalties in relation to [m]isconduct (including in the case of business partners, a plan to exit from the arrangement, such as a contractual right of termination, in the event that the business partner engages in [m]isconduct))."

86. ICC, ICC Anti-Corruption Clause 1 (2012), http://icc.tobb.org.tr/docs/ICCAnti-corr uptionClauseebook.pdf [https://perma.cc/MN2U-UBVJ].

87. $I d$. at 2.

88. Id. The ICC presents two options for inclusion, either by reference or by incorporation of the full text of Part I, as in some jurisdictions incorporation by reference may be inadequate to create legal effects. See Lauri Railas, The Origins and Advantages of the International Chamber of Commerce Anti-Corruption Clause, ETHIC INTELLIGENCE (Nov. 15, 2013), https://www.ethic-intelligence.com/en/resources/experts-corner/internation al-experts/217-the-origins-and-advantages-of-the-icc-anti-corruption-clause.html [https://per ma.cc/PU2D-8ET2] (analyzing the ICC Clause).

89. Id. at 4 . 
laundering, and that they will take "reasonable measures" to ensure that the third parties they engage will likewise refrain from such activity. ${ }^{90}$ Finally, the first alternative provides a right to suspend or terminate the contract if a party provides evidence that its counterparty has materially breached the above anti-corruption provisions, and the counterparty fails to take the necessary remedial action. ${ }^{91}$ Upon notice of apparent breach, the notified counterparty may invoke a defense by proving that, at the time the evidence of breach had arisen, it had implemented "adequate anti-corruption preventive measures . . . capable of detecting corruption and of promoting a culture of integrity in its organization." 92

The second alternative offers a weaker undertaking for the contracting parties. It mandates that each party simply commits to putting into place a corporate anti-corruption compliance program at the time the parties enter into the contract or soon thereafter, and advises that the compliance program should be "adapted to [each party's] particular circumstances and capable of detecting corruption and of promoting a culture of integrity in its organization."93 The parties must maintain such program throughout the contract's lifetime, ${ }^{94}$ and if one party proffers evidence that the counterparty's compliance program contains material deficiencies that undermine its efficiency, it can require the counterparty to take remedial action upon notice. If the counterparty fails to remediate, the notifying party has the right to suspend or terminate the contract. ${ }^{95}$

The Global Infrastructure Anti-Corruption Centre (GIACC) also issued guidance on anti-corruption model clauses that can be included in organizations' contracts with business associates, and the GIACC model terms expand the range of anti-corruption commitments beyond those

90. Id. In connection with taking "reasonable measures" with third party agents, the ICC Clause mandates that the contracting parties "should instruct them neither to engage nor to tolerate that they engage in any act of corruption; not use them as a conduit for any corrupt practice; hire them only to the extent appropriate for the regular conduct of the [p]arty's business; and not pay them more than an appropriate remuneration for their legitimate services." ICC, supra note 86 , at 5.

91. Id. at 5. For a discussion on how a breach of a non-corruption obligation can be remedied, see Railas, supra note 88 (arguing that the breaches that are not attributable to the directing mind of an organization may be remedied by a reorganization of work, increased surveillance, or firing the individuals who committed the offense).

92. Id. at 5 .

93. Id. at 5. Lauri Railas explains that the ICC included the second alternative in the final days of preparation to address concerns over a contracting party's improper motives. See Railas, supra note 88 (explaining that "[t]here was a fear that random actions of insignificant employees would jeopardise the existence of a long-term contractual relationship in a situation where a contracting partner wants to get rid of a binding contract that has become disadvantageous due to commercial developments.").

94. ICC, supra note 86 , at 5 .

95. Id. at 6 . 


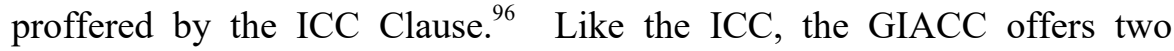
contractual alternatives, with the first constituting a simple commitment for the contracting business associate "not to participate in any corrupt conduct." $" 97$ The second alternative offers more comprehensive anticorruption commitments for an organization's choosing, including provisions concerning corruption prevention, training, auditing, investigating, and termination rights. ${ }^{98}$

The GIACC's more comprehensive provisions mandate that, inter alia, the business associate agree that it, its personnel, subsidiaries, and related companies will not participate in any corrupt practices relating to the contract and that it will take reasonable steps to ensure that its agents and associates do not participate in any corrupt practices. ${ }^{99}$ The business associate must also confirm that it, its owners, directors, and managers "have not been investigated, convicted or debarred for corruption."100 Moreover, the business associate must agree to provide anti-corruption training to its personnel, and allow the contracting counterparty to (i) audit the business associate in relation to the underlying transaction, ${ }^{101}$ (ii) undertake an investigation in the event of suspected or actual corruption

96. GIACC, Contract Terms $\S \S 1-5$ (Feb. 19, 2016), http://www.giaccentre.org/contract _terms.php [https://perma.cc/5DVF-PDM8] [hereinafter GIACC Contract Terms]. The GIACC is an independent non-profit organization whose mission is to provide resources to assist in understanding, identifying, and preventing corruption in the infrastructure, construction, and engineering sectors. GIACC, About GIACC (Sept. 14, 2018), http://www. giaccentre.org/index.php [https://perma.cc/QE3N-C8UD].

97. GIACC Contract Terms, supra note 96, at $\S 4$. The GIACC defines a "business associate" to mean "any party with which the organisation contracts, including but not limited to clients, customers, joint venture partners, consortium partners, contractors, consultants, sub-contractors, suppliers, vendors, advisors, agents, distributors, representatives and intermediaries (but excluding the organisation's personnel)." GIACC, Business Associate Corruption Risk Assessment (Feb. 22, 2016), http://www.giaccentre.org/ RiskAssessment-BusinessAssociate.php [https://perma.cc/5DVF-PDM8] [hereinafter GIACC Corruption Risk Assessment].

98. GIACC, Sample Anti-Corruption Contract Commitments $\S 11-12$ (Feb. 19, 2016), http://www.giaccentre.org/documents/GIACC.WEBSITE.CONTRACTTERMS.SAMPLE.d ocx [https://perma.cc/5V3A-VB33] [hereinafter GIACC Sample Commitments].

99. GIACC Contract Terms, supra note 96, at $\S 5$. The GIACC defines corrupt conduct to include bribery, extortion, fraud, cartels, abuse of power, embezzlement, and money laundering. GIACC Sample Commitments, supra note 98, at 1.

100. GIACC Contract Terms, supra note 96, at $\S 5(\mathrm{c})$. Under this provision, the business associate also agrees to notify its counterparty immediately in writing if at any time it becomes aware of any such investigation, conviction, or debarment. GIACC Sample Commitments, supra note 98 , at $\S 2$ (b).

101. The purpose of the audit is for an organization to ensure as far as practicable that any payments it made to the business associate under the contract have not been used corruptly. GIACC Sample Commitments, supra note 98, at $§ 7$. 
involving the business associate, ${ }^{102}$ and (iii) terminate the contract immediately in the event that the business associate breaches any of the anti-corruption provisions. ${ }^{103}$ Finally, the business associate must agree to indemnify the counterparty for any liability or loss suffered due to any breach by the business associate of the anti-corruption provisions. ${ }^{104}$

\section{Parties May Harness Broad Powers Through an Expanded Range of Anti-Corruption Commitments}

Anti-corruption contractual provisions offer basic protection that can address compliance obligations under the FCPA, UK Bribery Act, and other applicable laws when a company enters into an agreement with a business associate. Contracting parties may avail themselves of a wide range of anti-corruption undertakings and representations that can further strengthen anti-corruption commitments and that extend beyond those proffered by the ICC Clause and the GIACC model provisions. Such clauses fall into nine broad categories: (i) representations and warranties pertaining to compliance with relevant anti-corruption laws, (ii) rights to conduct audits of the third party's books and records, (iii) termination rights connected to any breach of the anti-corruption provisions, (iv) indemnification rights, (v) cooperation rights, (vi) restrictions on the use of sub-contractors, (vii) on-going training requirements, (viii) annual certification requirements, and (ix) re-qualification requirements.

\section{i. Representations \& Warranties Pertaining to Anti-Corruption Compliance}

To follow a minimal requirement for an anti-corruption contractual commitment, a company can implement as an administrative procedure including in contracts between the company and any relevant business associate a simple provision that prohibits corruption. ${ }^{105}$ The clause could

102. The investigation provision requires the business associate to "provide all reasonable assistance, information and documentation to [the counterparty] during the course of the investigation." GIACC Sample Commitments, supra note 98, at $\S 10$.

103. GIACC Contract Terms, supra note 96, at $\S 5(\mathrm{~g})$.

104. Id. at $\S 5(\mathrm{~h})$.

105. Corrupt practices are typically defined to include bribery, extortion, fraud, abuse of power, cartels, embezzlement, money laundering, and any similar activities. See GIACC Sample Commitments, supra note 98, at 1 (defining corrupt practices); INT'L FIN. INSTS. Anti-Corruption Task Force, Uniform Framework for Preventing and Combating FRAUD AND CORRUPTION 1 (Sept. 2006), https://www.afdb.org/fileadmin/uploads/afdb/ Documents/Generic-Documents/Uniform_Framework_for_Combatting_Fraud_and_Co rruption.pdf [https://perma.cc/YNE3-YAYT] (defining fraudulent and corrupt practices). 
require the parties to agree that they have not, and will not, participate in any corrupt practices in relation to the contract. ${ }^{106}$ The ASCO Transport \& Logistics client terms \& conditions contract contains a clause that exemplifies this approach, where "[e]ach party warrants and represents that in negotiating and concluding the contract it has complied, and in performing its obligations under the contract it has complied and shall comply, with all applicable anti-bribery laws." ${ }^{107}$

A company could more rigorously expand the scope of this clause, thereby expanding its protection, such that the business associate agrees to ensure that its personnel, partners, sub-contractors, suppliers, consultants, and other agents, as well as its subsidiaries and related companies, will not participate in any corrupt practices related to the contract. It could further supplement this protection by requiring the business associate to confirm that it, its owners, directors, and officers have not been investigated, convicted, or debarred for corruption. ${ }^{108}$ In connection with such provisions, some companies make reference to their business partnerspecific ethical codes of conduct to set broader ethical expectations. ${ }^{109}$

Finally, a company could require the business associate to warrant further that the business associate has implemented an anti-corruption compliance program that sets out adequate procedures designed to comply with the applicable anti-corruption laws and that the business associate will

106. Per the British Bankers' Association (BBA) guidance, "[t]he contracts should warrant that the associated person has not and will not breach relevant anti-corruption laws." Meloni \& Ereira, supra note 7, at 6 (quoting the BBA guidance).

107. ASCO Transport \& Logistics, AT\&L Client Terms \& Conditions $\S 28.1$ (Mar. 2, 2017), http://www.ascoworld.com/atl/images/terms_and_conditions.pdf [https://perma.cc/38 J3-44KM] [hereinafter ASCO T\&L]. Accord TUI Group, Information on the AntiCorruption Clause (2018), https://www.tuigroup.com/en-en/meta/purchase_conditions/anticorruption-clause [https://perma.cc/F6Q7-FDAP] (stating that "[t]he supplier agrees to comply with all German legislation to combat corruption in the execution of the contractually agreed services"). For an alternative approach that includes bribery-specific compliance template language, see Michael Volkov, Contracts and Anti-Corruption Compliance (July 17, 2011), https://blog.volkovlaw.com/2011/07/contracts-and-anti-corrupt ion-compliance/ [https://perma.cc/DE7C-4PDM] (providing that the business associate in all undertakings "will make no payments of ... anything of value, nor will such be offered, promised, or paid, directly or indirectly, to any foreign officials, political parties, party officials, candidates for public or political party office, to influence the acts of such [persons] in their official capacity, to induce them to use their influence ... to obtain or retain business or gain an improper advantage in connection with any business venture or contract in which the company is a participant").

108. See McInnes, supra note 64 , at 3 (discussing anti-corruption contractual warranties).

109. See, e.g., Phillips 66, Standard Compliance Clauses 1-2 (Jan. 20, 2017), https:/www.phillips66.co.uk/EN/about/commercial-uk/Documents/compliance\%20clauses \%20\%20trading\%20170124.pdf [https://perma.cc/DE7C-4PDM] (referencing standards of business ethics and business partner principles of conduct). 
maintain and comply with its program for the duration of the contract. ${ }^{110}$ Veolia follows this approach in its agreements with its suppliers, where a "[s]upplier undertakes to put in place and implement all necessary and reasonable policies and measures to prevent corruption." 111 Such a provision effectively compels the business associate to maintain an internal anti-corruption compliance program for the duration of the contract.

\section{ii. Rights to Conduct Audits on a Counterparty}

As corruption by its nature transpires in secrecy, typically leaving no evidence trail, a company faces practical difficulties in determining whether its business partner has infringed upon an anti-corruption provision in an agreement. ${ }^{112}$ The conclusions of an audit of a business partner's financial books and records may produce evidence of infringement, rendering an audit one of the few means for companies to detect corruption and resulting infringement by a business partner. ${ }^{113}$ A contractuallyprovided audit right can accordingly provide a party with a mechanism to monitor compliance with its anti-corruption commitments. The purpose of the audit confirms to a party that, as far as practicable, no payments made by that party to its counterparty under the agreement have been used corruptly. ${ }^{114}$ Parties can draft audit rights provisions to provide assurance that a counterparty maintains accurate financial books and records and well-functioning anti-corruption internal controls. ${ }^{115}$

Companies have also drafted audit rights provisions to include an express right to audit the existence, content, and implementation of a

110. See ASCO T\&L, supra note 107, at $\S 28.2$ ("The contractor warrants that it has [a compliance program] setting out adequate procedures to comply with applicable anti-bribery laws and that it will comply with such [compliance program] in respect of the contract").

111. Veolia, Anti Corruption Clause $\S 1.3$ (2018), https://www.veolia.com/anz/anti-co rruption-clause-0 [https://perma.cc/UT43-N6SQ].

112. See, e.g., JSG Trading Corp. v. United States Dep't of Agric., 176 F.3d 536, 545 (D.C. Cir. 1999) (stating that "[w]ithout a finding of secrecy and intent to induce, there appears to be nothing to distinguish an illegal bribe from a simple promotional gift"); United States v. Holzer, 816 F.2d 304, 309 (7th Cir. 1987) (observing that "no public official ... takes bribes openly"); Sirkin v. Fourteenth St. Store, 124 A.D. 384, 391 (N.Y. App. Div. 1908) (remarking that "[t]he vice [of bribery] lies in making the agreement without the knowledge of the master").

113. Witness statements, particularly as a result of a whistleblowing mechanism, are another avenue to produce such evidence. See ICC, supra note 86, at 10 (discussing evidence of non-compliance with anti-corruption commitments).

114. See GIACC Sample Commitments, supra note 98, at $\S \S 4-8$ (detailing the purpose of audit rights provisions).

115. See Grimm, supra note 64, at 147 (explaining that audit rights provide insurance that books and records are accurate, and the counterparty has strong internal controls). 
counterparty's compliance program. ${ }^{116}$ From the range of anti-corruption provisions available, audit rights provisions are possibly the most contentious, due to the intrusive nature of the audit process. In the event of objections, a party can narrow the scope of audit rights to apply only to those financial records that pertain to the performance of the relevant contract, or structure the audit provisions such that a third party would conduct any audit, to overcome the possibility of such objections. ${ }^{117}$

The DOJ has signaled the importance of audit rights in its issued FCPA guidance to individuals and companies ${ }^{118}$ and through its Opinion Procedure Releases, ${ }^{119}$ where the inclusion of audit rights in contracts with business partners comprised a feature of the opinion requestors' compliance programs. ${ }^{120}$ The Ministry of Justice likewise has acknowledged the significance of including such provisions in contracts with business partners to prevent bribery. ${ }^{121}$

116. See ASCO T\&L, supra note 107 , at $\S 28.3$ (saying "on provision of no less than thirty (30) days' formal notice, the Company ... shall have the right to audit, at its own cost, the existence, content and implementation of the Contractor's [compliance program], but such right shall not include access to documents that are legally privileged or were created for the purpose of an on-going internal investigation"); PAUL MARSHALL \& EVE

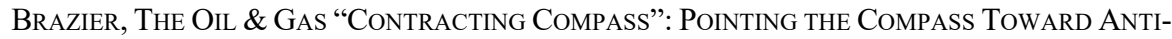
BRIBERY \& CORRUPTION 12 (Dec. 8, 2017), https://brodies.com/sites/default/files/brodies_ll p_-_anti-bribery_corruption_white_paper.pdf [https://perma.cc/8N8Q-HDLW] (analyzing audit rights provisions).

117. Angela M. Xenakis, Contracting with Third-Party Reps: FCPA Risks, LAw360 (Aug. 1, 2012, 1:46 PM), https://www.law360.com/articles/361944/contracting-with-third-p arty-reps-fcpa-risks [https://perma.cc/XJ6D-RGCL].

118. See FCPA ResourCe Guide, supra note 25, at 60 (saying that "companies should undertake some form of ongoing monitoring of third-party relationships ... this may include ... exercising audit rights").

119. The FCPA Opinion Procedure process allows private parties to obtain the DOJ's opinion as to whether certain specified, prospective - not hypothetical-conduct conforms with the DOJ's present enforcement policy regarding the anti-bribery provisions of the FCPA. Foreign Corrupt Practices Act Opinion Procedure, 28 C.F.R. § 80.1 (2014).

120. See U.S. Dep't of Justice, FCPA Opinion Procedure Release 2004-02 (July 12, 2004), https://www.justice.gov/sites/default/files/criminal-fraud/legacy/2010/04/11/0402.pd $\mathrm{f}$ [https://perma.cc/CZ2H-M4P9] (acknowledging the "inclusion in all agreements ... with all ... Business Partners of provisions ... allowing for internal and independent audits of the books and records of the ... Business Partner to ensure compliance with the [anticorruption contractual provisions]"). See also DOJ Release 2008-02, supra note 68 (making a similar acknowledgement).

121. BRIBERY ACT GUIDANCE, supra note 32, at 39 (acknowledging the inclusion of "suitable contractual terms on bribery prevention measures in [an] agreement between [parties], for example: ... giving [one party] the ability to audit [the counterparty's] activities and expenditure"). 


\section{iii. Addressing Infringement Through Termination, Suspension, Cooperation and Indemnification Rights}

If a party breaches its obligations under an anti-corruption clause, the breach may trigger termination of the contract. Options abound, as parties may include rights to suspend and terminate a contract unilaterally in the event of a material breach of an anti-corruption commitment within, ${ }^{122}$ such as a party violating an applicable anti-corruption law. ${ }^{123}$ A party can further include in the provision an agreement that in the event corrupt payments are made in connection with the contract, the contract is void, and deem any violation of an applicable anti-corruption law to constitute grounds for withholding any outstanding payments related to the illicit conduct. ${ }^{124}$

Parties can structure a termination right to provide the alleged breaching party an opportunity to remedy a suspected breach ${ }^{125}$ if such remedy is possible under the circumstances. ${ }^{126}$ In some instances, companies include an obligation to notify in connection with any instance of corruption, essentially requiring their suppliers as part of their engagement terms and conditions to notify within a reasonable time any breach of any anti-corruption clause. ${ }^{127}$ When a party exercises its right of termination, it typically bears the burden of proof that its counterparty has

122. See, e.g., Phillips 66, supra note 109, at 2 (stating that "[e]ither party may terminate the [a]greement forthwith upon written notice to the other at any time, if in its reasonable judgement, the other is in breach of any of the representations, warranties or undertakings in this anti-corruption section"); Veolia, supra note 111, at $\S 7$ (saying that "[i]f Supplier breaches any term of this [anti-corruption] clause: ... Veolia may immediately terminate this [a]greement without notice and without incurring any liability").

123. See Xenakis, supra note 117 (advising to "[i]nclude a provision stating that a violation of anti-corruption laws constitutes a material breach of contract").

124. Xenakis, supra note 117. But see MARSHAll \& BRAZIER, supra note 116 , at 13 (explaining that " $[t]$ he right to suspend payment is not an absolute right but is qualified by reasonableness").

125. See ASCO T\&L, supra note 107, at $\$ 28.5$ (a) (stating that "if the C[ompany] has a reasonable belief that the $\mathrm{C}$ [ontractor] has breached [the anti-corruption commitments], the C[ompany] may give formal notice of its intention to suspend payments under the $\mathrm{C}$ [ontract] to the C[ontractor] ... [and] [i]f within seven (7) days of receipt... the $\mathrm{C}$ [ontractor] neither responds with information reasonably satisfactory to the C[ompany] to refute such belief nor commences and continues with action reasonably satisfactory to the C [ompany] to remedy such suspected breach ... the C[ompany] may ... suspend with immediate effect any payments due ... without liability").

126. While certain infringements may be impossible to remedy (e.g., a party engaging in criminal activity), the ICC provides examples of possible remedial actions where the gravity of infringement is relatively minor: issuing warnings, reorganizing work, terminating employment for any personnel involved in misconduct, terminating contracts with any subcontractors involved in misconduct. ICC, supra note 86, at 9.

127. Veolia, supra note 111 , at $\S 5$. 
infringed the relevant anti-corruption provision(s). ${ }^{128}$

Suspension rights allow a company to suspend performance of the relevant contract and any associated payments thereof, with or without notice, often for either a defined period, or for as long as the company considers necessary to investigate any alleged infringement by its business partner of any material anti-corruption provision. The company in drafting a suspension rights clause can include language noting that it will not incur liability or obligation to its counterparty for exercising a suspension right. ${ }^{129}$ Moreover, a company can obligate its business partner by contract to initiate a document hold exercise where the business partner agrees to take all reasonable steps to prevent the loss or destruction of any documentary evidence related to the relevant alleged infringing conduct. ${ }^{130}$

In connection with suspension rights, the company can also require its business partner to provide all reasonable information, documentation, and assistance to the company during the course of the investigation. ${ }^{131}$ Such a cooperation right can require a business provider to cooperate fully with any corruption-related investigation, including the review of any emails and bank account information pertinent to the underlying transaction. ${ }^{132}$

In the event a party breaches an anti-corruption clause, an indemnification provision requires the breaching party to agree to indemnify its counterparty for damages, losses, or expenses incurred by that counterparty arising out of the breach. ${ }^{133}$ The provision can cover the indemnified party's expenses from any corruption investigation or prosecution brought about by the breaching party's activities. ${ }^{134}$ Certain

128. See ICC, supra note 86 , at 10 (analyzing the effects of termination and specifying that amounts contractually due at the time of termination typically remain payable, if permitted by applicable law).

129. See Veolia, supra note 111 , at $\S 6.1$ (asserting a suspension right without notice).

130. Id. at $\S 6.2$.

131. GIACC Sample Commitments, supra note 98 , at $\S 10$.

132. See Volkov, supra note 107 (describing the compliance provisions that should be included in business partner contracts).

133. See Veolia, supra note 111 , at $\S 7.2$ (asserting an indemnification right to the maximum extent allowed by law); Joanna Kay, Anti-Corruption Provisions and Upstream Joint Ventures—Boilerplate or Bespoke?, MONDAQ (Apr. 20, 2015), http://www.mondaq.co $\mathrm{m} /$ unitedstates/x/390538/Oil+Gas+Electricity/AntiCorruption+Provisions+and+Upstream $+\mathrm{J}$ oint+Ventures+Boilerplate+or+Bespoke [https://perma.cc/VL2Q-VYXD] (explaining that each party may undertake to indemnify the other for any losses suffered as a result of the admission of allegations of an anti-corruption violation, or the final adjudication that there has been a corruption violation applicable to that party).

134. See Xenakis, supra note 117 (describing termination provision structuring). For a sample anti-corruption indemnity clause. See also Shevan Algama, BIMCO AntICORRUPTION Clause 2 (Apr. 18, 2016), https://www.shipownersclub.com/media/2016/04/B IMCO-Anti-Corruption-Clause.pdf [https://perma.cc/DBD4-D2TV] (remarking that "[i]f either party fails to comply with any applicable anti-corruption legislation it shall defend 
indemnities however may be contrary to public policy and unenforceable, such as an indemnity to cover criminal fines and penalties. ${ }^{135}$

\section{iv. Additional Rights, Restrictions, and Requirements Available by Contract}

The remaining set of rights and restrictions available to contracting parties largely center upon ongoing compliance monitoring and review. In connection with a party's engagement of subcontractors, a company can require its business partner to agree that it will not engage any subcontractor, consultant, or other agent without the company's prior written consent. ${ }^{136}$ Such a restriction may allow either contracting party to conduct appropriate anti-corruption due diligence on any proposed intermediary. ${ }^{137}$ The company can ensure that any intermediaries are instructed not to engage in any corrupt practice, hired only to the extent appropriate in connection with the underlying transaction, and paid only an appropriate remuneration for legitimate services provided. ${ }^{138}$

On-going training requirements require that a party undertake any pertinent anti-corruption training that its counterparty reasonably requires. The counterparty requiring such training is often responsible under the terms of the agreement for the costs of any such training. ${ }^{139}$ The purpose of this provision aims to ensure that a business partner's relevant personnel receives anti-corruption training. ${ }^{140}$ The business partner's top management and all persons performing services in connection with the underlying transaction would presumably receive such training too. ${ }^{141}$

Annual certification clauses typically require a counterparty to certify that it remains aware of its anti-corruption obligations, it has not engaged in

and indemnify the other party against any fine, penalty, liability, loss or damage and for any related costs (including, without limitation, court costs and legal fees) arising from such breach").

135. Lincoln Logan Mut. Ins. Co. v. Fornshell, 722 N.E.2d 239, 242 (Ill. Ct. App. 1999) (“An agreement to indemnify against intentional misconduct would, as a general rule, be contrary to public policy and unenforceable.... [C]riminals should not be permitted to profit from their own intentional misconduct.") (internal citations omitted). See also MARSHALl \& BRAZIER, supra note 116, at 6 (discussing how criminal fines are not insurable in England and Wales).

136. See Volkov, supra note 107 (discussing subcontractor compliance efforts).

137. See McInnes, supra note 64 (examining intermediary due diligence initiatives); see also Xenakis, supra note 117 (discussing intermediary due diligence initiatives as well).

138. ICC, supra note 86 , at 8 (providing a sample provision addressing intermediaries).

139. GIACC Sample Commitments, supra note 98, at $\S 3$ (evaluating training obligations).

140. GIACC Contract Terms, supra note 96, at $\S 5(\mathrm{~d})$.

141. See Volkov, supra note 107 (analyzing training best practices). 
conduct that violates any applicable anti-corruption laws, and it is not aware of any such conduct by its employees and agents. ${ }^{142}$ Finally, requalification clauses require a counterparty to re-qualify as a legitimate business partner at regular intervals. ${ }^{143}$ The re-qualification process allows a party to conduct updated due diligence on its business partner and review the relevant contract during its lifespan to assess any corruption concerns that may have arisen. ${ }^{144}$

\section{RECOMMENDATIONS FOR HARNESSING CONTRACTUAL LAW TO FigHT CORRUPTION IN THE CORPORATE SECTOR}

Anti-corruption provisions in contracts with third parties constitute a critical soft-law initiative that can facilitate constraining corruption in international business transactions. ${ }^{145}$ From a corporate perspective, they provide a means for private sector entities to signal their commitment to abiding by pertinent anti-corruption law(s), to integrate anti-corruption commitments into their commercial dialogue with agents, to strengthen the monitoring and supervision of projects with such agents, and to address corruption risks at all stages of the pertinent contract's lifespan with predictability. ${ }^{146}$ From the perspective of corporate directors and officers, who potentially face personal liability for attributable breaches of their company's business partners, the provisions reduce the risk of liability for these individuals. More broadly, the provisions promote greater corporate transparency and disclosure, "help preserve trust between [contracting] parties and prevent corruption in both the negotiation and performance of contracts." $" 147$

142. See Xenakis, supra note 117 (providing an overview of annual certification requirements in contract).

143. See Volkov, supra note 107 (discussing re-qualification obligations for contracting parties).

144. See McInnes, supra note 64 (noting the use of anti-corruption clauses in supply chain and subcontractor contracts).

145. See Susan Rose-Ackerman \& Sinéad Hunt, Transparency and Business Advantage: The Impact of International Anti-Corruption Policies on the United States National Interest, 67 N.Y.U. AnN. SuRv. Am. L. 433, 433 (2012) (discussing benefits and costs to the U.S. from anti-corruption soft-law initiatives).

146. See Marie Chêne, Examples of Anti-Corruption Clauses in Cooperation AGREEMENTs 1 (Mar. 25, 2010), https://www.u4.no/publications/examples-of-anti-corruptio n-clauses-in-cooperation-agreements.pdf [https://perma.cc/PR8G-87R8] (demonstrating the role of anti-corruption clauses in cooperation agreements).

147. Allen, supra note 1 . 


\section{A. Harmonizing Anti-Corruption Compliance Program Operations with Contractual Provisions Through Structured Risk Management}

Any company seeking to avoid corrupt practices abroad should construct an effective anti-corruption compliance program through a structured risk management approach, whether that company is a multinational corporation or simply conducts business overseas. ${ }^{148}$ An increasingly critical feature of the compliance program involves conducting due diligence on the selection and retention of any third party that aims to serve as agent. Programs should facilitate as part of their mission the use of anti-corruption provisions in contracts with third party agents, given companies can be held liable for the acts of its agents under the FCPA and UK Bribery Act. ${ }^{149}$ Companies should design such programs with adequate resources and with the objective to assess and address firmly the nature and scope of corruption risks at all stages of engagement with any third-party agents subject to company control or determining influence. The programs should be capable of detecting corruption and should accordingly allow for training of company directors, officers and employees. Inclusion of anticorruption contractual provisions serves as an effective corporate tool functioning as a component of a company's larger compliance program.

Companies face three disparate options in including anti-corruption provisions within contracts with third-party agents: whether to include the provisions in all of their contracts, in contracts over a certain amount, or to include depending upon the results of a risk assessment exercise, where companies assess, inter alia, the underlying risk, the business relationship and commercial needs, and the nature of the negotiations. Very few companies follow the latter approach, ${ }^{150}$ which allows companies to construct a specific model of risk assessment that best suits their purposes. The risk assessment model categorizes agents into risk bands by reference to specific objective criteria and applies different levels of due diligence and internal controls to such agents according to the criteria. ${ }^{151}$

A risk-based approach presents an optimal method, as it can offer

148. For an overview of corporate compliance programs tailored to address international white-collar crime, see Colin R. Jennings, Avoiding Criminal Liability for Corrupt Practices Abroad Through Effective Corporate Compliance, 2011 WL 6740787, at*1 (2011).

149. See supra Part I.B (detailing the FCPA and UK Bribery Act liability provisions); Jennings, supra note 148 , at *6 (analyzing due diligence inquiries pertinent to third party agents).

150. Eduard Ivanov et al., Legal Regulation of Combating Corruption: Report of the LSGL's Research Group 14 (Law Schs. Glob. League, Research Paper No. 2, 2014), https:/ /ssrn.com/abstract=2461487 [https://perma.cc/C76B-G8CN].

151. See GIACC Corruption Risk Assessment, supra note 97, at 1 (providing detailed guidance on business associate corruption risk assessment). 
simplicity and proportionality to companies by providing the ability to group anti-corruption clauses into risk bands to be deployed based upon appropriate risk categories as a result of the risk assessment conducted. A simple example of a tiered approach involves standard anti-corruption provisions for lower risk relationships (such as for supply chain partners who have existing, robust compliance programs in operation) and enhanced provisions for higher risk relationships (such as for joint ventures, consultants, and counterparties operating in countries classified with high corruption risk). ${ }^{152}$ Such an approach may avoid unnecessarily burdensome obligations in connection with lower risk relationships. ${ }^{153}$

Some advocate for the blanket inclusion of anti-corruption provisions in all third-party contracts, ${ }^{154}$ but the use of robust provisions may add unnecessary cost and inconvenience to the business relationship. While no contract modality is free from corruption risks, ${ }^{155}$ longer term contracts, contracts with large magnitude or complexity, and acquisition contracts present higher risk, along with contracts with higher risk business associates. ${ }^{156}$ Companies entering into such high-risk contracts could benefit from including an expansive set of anti-corruption protections as discussed in Part II. For instance, inserting a warranty for an agent's compliance with anti-corruption law may entitle an innocent party in the event of corruption to a civil claim for breach of contract and to recover damages that would not otherwise arise under the relevant statutory provisions. ${ }^{157}$

Termination is notably the most effective mechanism for a company to disavow itself of its counterparty's corrupt activities. ${ }^{158}$ While companies generally allow for the immediate termination of the relevant contract if a counterparty violates any pertinent anti-corruption law or any substantive anti-corruption contractual provision, companies seldom include penalty clauses within their anti-corruption provisions. ${ }^{159}$ Penalties obligating a non-compliant party to reimburse its innocent counterparty for any fines and losses incurred as a result of the non-compliance, in addition to the innocent party's unilateral right to terminate the agreement, may be an efficient starting approach for negotiations in order to address a party's

152. See McInnes, supra note 64 (outlining steps for risk assessment).

153. Id.

154. Jennings, supra note 148 , at $* 14$ (advising companies to "include anticorruption elements in contracts wherever possible").

155. CHÊNE, supra note 146, at 1 (providing overview of corruption risk).

156. See Railas, supra note 88 (detailing business arrangements carrying high corruption risk).

157. MARShALl \& BRAZIER, supra note 116 , at 10-11.

158. See Xenakis, supra note 117 (noting the benefits of anti-corruption provisions).

159. Ivanov et al., supra note 150 , at 14. 
potential failure to comply. The provisions in sum should "shield[] each party from the corrupt practices of the other, while preserving the continuity of their contractual relationship."

Any set of anti-corruption provisions should at minimum include an agreement that the parties have and will comply with the applicable anticorruption laws, with clear definitions and descriptions of prohibited conduct, and an agreement that the parties will implement reasonable and necessary policies and practices to prevent corruption while the contract remains in force. The provisions should also allow for a party to conduct legitimate inquiries should red flags arise during the contract's duration. ${ }^{161}$ More expansive provisions providing for training, audit, investigation, termination and indemnification rights can solidify further the parties' anticorruption commitments and protections if necessary given the risk levels present. ${ }^{162}$

\section{B. Enhancing Anti-Corruption Initiatives Globally Through Expansive Use of Anti-Corruption Provisions}

The use of anti-corruption provisions in contracts with foreign parties who would otherwise not be obligated to respect anti-corruption legislation serves to advance international anti-corruption objectives. ${ }^{163}$ The provisions can compel foreign parties to respect anti-corruption legislation of other jurisdictions, to implement internal anti-corruption compliance policies and programs, and to subject their facilities and financial statements to audit. ${ }^{164}$ Potential substantive sanctions for noncompliance would increase the likelihood that such parties carry out their obligations under these provisions. For these reasons, the provisions may assist in shifting norms toward corporate anti-corruption commitments on a global level and raising awareness of the need to avoid corruption. They signal to all involved that corrupt actions will not be tolerated. ${ }^{165}$

Regardless of its location, a company could take the position that anticorruption contractual provisions are extraneous contract mechanisms that

160. Allen, supra note 1.

161. See Xenakis, supra note 117 (noting the benefits granted by an anti-corruption provision).

162. See supra Part II.C (discussing the comprehensive set of anti-corruption provisions available to parties).

163. See supra Part I (discussing international anti-corruption initiatives).

164. See Guarderas, supra note 8 (bringing attention to the powers of anti-corruption clauses).

165. See Allen, supra note 1 (recommending the incorporation of anti-corruption clauses into contracts). 
may cause the company to lose business to (corrupt) competitors. ${ }^{166}$ Such a position ignores the significant liability risks under the FCPA, Bribery Act and other laws companies may face in connection with the corrupt activities of their third-party agents, as well as the economic harm corruption brings to the private sector. ${ }^{167}$ Moreover, companies using the provisions have a mechanism to oppose corrupt payments and to monitor their agents' behavior without any external pressure from law enforcement. Individual profit-maximization and the avoidance of corruption can harmonize together through effective provision usage. ${ }^{168}$

From a public policy perspective, anti-corruption contractual provisions can reinforce a strong corporate stance against foreign bribery and other forms of corruption and signal the value of an honest business environment. The provisions allow corporations to participate in global anti-corruption efforts, help level the corporate playing field, and harmonize with international public order. ${ }^{169}$ The 10th Principle of the UN Global Compact implores companies to "work against corruption in all its forms, including extortion and bribery," calling on companies to develop policies and practices to address corruption: "We challenge companies to join peers, governments, UN agencies and civil society to realize a more transparent global economy." "170 Anti-corruption provisions harmonize with this movement.

\section{Recognizing the Limitations of Anti-Corruption Contractual Provisions for Corporate Actors}

While anti-corruption provisions offer benefits directly to companies and more broadly to the larger society in connection with combatting corruption, the provisions are not a compliance panacea for the company that engages third-party agents. The provisions alone constitute insufficient protection for companies in connection with their liability under anti-bribery laws, as companies should integrate these provisions

166. Cf. Richard Levick, The Foreign Corrupt Practices Act at 40: No Shortage of Challenges, Forbes (May 16, 2017), https://www.forbes.com/sites/richardlevick/2017/05/1 6/the-foreign-corrupt-practices-act-at-40-no-shortage-of-challenges/\#25f81c3a5f90 [https:// perma.cc/JS8N-9Y95] ("Detractors [of the FCPA] say its benefits are exaggerated, that it puts American companies at a competitive disadvantage, and that its compliance costs are prohibitive for many companies.").

167. See supra Part I.A (analyzing the effects of corruption upon economic growth).

168. See Rose-Ackerman \& Hunt, supra note 145, at 461-62 (examining how corruption can introduce inefficiencies that decrease competitiveness).

169. ICC, supra note 86 , at 1.

170. Das, supra note 48. 
into a larger anti-corruption compliance program. ${ }^{171}$ Government agencies in assessing a company's compliance with and liability under anticorruption law may look to whether the company not only adopts but also enforces anti-corruption provisions where reasonable in its contracts with counterparties and links such enforcement to a larger compliance program. ${ }^{172}$ Companies arguably court liability if they use anti-corruption provisions in their contracts as mere boilerplate without giving the attendant obligations under the provisions due attention.

Companies should not over-engineer anti-corruption provisions when drafting, such that the provisions are imbalanced, one-sided and onerous, potentially reaching beyond the law and potentially too broad to be practicable and enforceable. ${ }^{173}$ Given the various rules of contract interpretation, companies should ensure that the provisions receive respect and enforcement via the ordinary course of the parties' performance of their contractual obligations. ${ }^{174}$ The validity of these provisions have largely been untested in courts, and whether a court will enforce such provisions, interpret strictly or allow as a defense against a corruption provision based upon a default of a noncompliant counterparty remains to be seen. ${ }^{175}$ Whether such provisions will be deemed valid judicially should not weaken their intent when coupled with a company's robust anticorruption compliance program. ${ }^{176}$

Regardless of the anti-corruption provisions' specific breadth, they should present a balanced approach that effectively regulates and manages corruption risk. The provisions should neither be particularly onerous to the parties, nor disproportionate to the level of risk present, nor "create unexpected consequences by way of its exploitation for commercial

171. See supra Part II (discussing integration of anti-corruption provisions within corporate compliance program operations).

172. See Gordon Kaiser, Corruption in the Energy Sector: Criminal Fines, Civil Judgments, and Lost Arbitrations, 34 ENERGY L.J. 193, 210 (2013) (describing the U.S. Department of Justice's enforcement opinion procedure); Volkov, supra note 107 ("A company's commitment to anti-corruption compliance can be quickly tested by examining its contracting practices and its use of anti-corruption provisions."); Xenakis, supra note 117 ("The U.S. Securities and Exchange Commission and U.S. Department of Justice will expect companies to exercise such rights and will look unfavorably on companies that have included audit rights but not exercised them when there are red flags.").

173. See MARShall \& BRAZIER, supra note 116, at 9 (analyzing contract drafting principles).

174. Daniel Schimmel et al., Bridging the Cultural Gap in International Arbitrations Arising from FCPA Investigations, 39 FORDHAM INT'l L.J. 829, 838 (2016).

175. Allen, supra note 1.

176. Id. See also ICC, supra note 86, at 2 ("An entity, whether an arbitral tribunal or other dispute resolution body, rendering a decision in accordance with the dispute resolution provisions of the contract, shall have the authority to determine the contractual consequences of any alleged non-compliance with the [anti-corruption] [c]lause[s]."). 
purposes." 177 The provisions should reflect the parties' genuine intent to combat corruption and not function to exploit corruption as an unfair or sham mechanism for terminating contractual arrangements. ${ }^{178}$ For instance, the provisions should enable the parties to work together when confronting and resisting demands for illicit payments. ${ }^{179}$

\section{Encouraging the Usage of Anti-Corruption Provisions Through Expanded Domestic Legislation \& Regulation}

Over the last two decades, government enforcement agencies have been enforcing anti-corruption legislation with increased rigor, ${ }^{180}$ creating what has been deemed a "highly adversarial relationship between enforcement agencies and firms." 181 Companies may implement numerous strategies to reduce their exposure to corrupt practices, including robust due diligence, rigorous compliance systems and expansive contractual remedies, but these efforts may not ultimately protect when operating in an uncertain enforcement landscape. ${ }^{182}$

Given the degree of uncertainty surrounding the FCPA in particular, recent calls to amend this law abound. ${ }^{183}$ In connection with the corporate compliance function, Professor Steve Salbu argues for the establishment of "standards for rigorous compliance programs that would provide qualifying companies with a defense against entity liability for the corrupt behavior of individuals." 184 Under Salbu's proposal, business entities could enjoy robust, clearly defined defenses upon implementing qualifying good-faith compliance programs through well-articulated and formulated standards. ${ }^{185}$ His qualified good-faith compliance program defense can be further enhanced by explicitly incorporating the use of anti-corruption provisions with third-party agents as a required practice where appropriate.

177. Railas, supra note 88 .

178. See Kay, supra note 133 (examining termination rights).

179. See AlgAmA, supra note 134, at 1 (discussing contractual provisions that facilitate cooperation in connection with illegal payment requests in the shipping industry).

180. Michael S. Diamant et al., Sanctionable Practices at the World Bank: Interpretation and Enforcement, 18 U. PA. J. Bus. L. 985, 992 (2016).

181. Steven R. Salbu, Mitigating the Harshness of FCPA Enforcement Through a Qualifying Good-Faith Compliance Defense, 55 Am. Bus. L.J. 475, 475 (2018).

182. Daniel J. Grimm, Traversing the Minefield: Joint Ventures \& the Foreign Corrupt Practices Act, 9 VA. L. \& Bus. ReV. 91, 93 (2014).

183. See, e.g., Daniel J. Grimm, The Foreign Corrupt Practices Act in Merger and Acquisition Transactions: Successor Liability and Its Consequences, 7 N.Y.U. J.L. \& Bus. 247, 299-300, 331 (2010) (stating specific ways in which the uncertainty surrounding the FCPA could be resolved).

184. Salbu, supra note 181 , at 475.

185. Id. at 479 . 
Such a good-faith defense can offer a safe harbor in connection with third-party agent liability for companies that (i) insert substantive anticorruption provisions within their contracts with such agents and (ii) incorporate enforcement of such provisions as appropriate within a larger internal compliance program designed to comply with relevant anticorruption laws. Companies meeting the above conditions should enjoy a full defense from liability arising from corrupt acts of third-party agents. The "policies and procedures" defense to "failure to prevent" offenses under Section 7 of the Bribery Act could also benefit from legislative reform such that it explicitly endorses anti-corruption contractual provision usage as a compliance program component that shields entities from thirdparty liability concerns. ${ }^{186}$

Revising anti-corruption legislation such as the FCPA and Bribery Act in this manner could benefit both private and public sectors. The revisions could provide businesses with direct incentives to develop strong anticorruption compliance programs that use and enforce anti-corruption contractual provisions appropriately. The revisions could also decrease transaction costs related to uncertainty in the domestic and international marketplace, ${ }^{187}$ help prevent future corruption violations, facilitate companies' self-policing in the fight against corruption, and boost ethicscentered corporate cultures along with the credibility of government enforcement agencies. ${ }^{188}$

\section{CONCLUSION}

Contract law offers a unique platform to assist a company in avoiding corruption actions. Properly structured anti-corruption contractual provisions with third parties can significantly reduce legal and performance risks and reputational concerns associated with third-party corrupt action, provided the provisions receive due enforcement in conjunction with the operations of an internal compliance program. Companies can draft these provisions most effectively in a risk-sensitive manner, recognizing that using these provisions contributes toward an ultimate purpose of removing

186. See supra Part I.B (detailing the Bribery Act "policies and procedures" defense).

187. See Adam Prestidge, Avoiding FCPA Surprises: Safe Harbor from Successor Liability in Cross-Border Mergers and Acquisitions, 55 WM. \& MARY L. REV. 305, 333 (2013) ("A safe harbor rule ... removes the need to compensate for uncertainty with expensive due diligence, decreasing the costs of these types of transactions because companies are able to pursue transactions with greater assurance that even if violations exist, they will not be penalized for those violations if otherwise compliant.").

188. See Salbu, supra note 181, at 535 (noting the benefits of a compliance program defense to the credibility of the FCPA and the DOJ's and SEC's FCPA enforcement system and practices). 
corruption from the companies' relevant industries. 